\title{
Monitoring and Evaluating Cutting Tool Wear using a IFM G4 Microscope
}

\section{Miroslav Zetek, Tomáš Bakša, Václav Schorník, Ivana Zetková}

Faculty of Mechanical Engineering, University of West Bohemia. Univerzitní 8, 30614 Pilsen. Czech Republic. E-mail: mzetek@rti.zcu.cz, baksa@rti.zcu.cz, schorník@rti.zcu.cz, zetkova@rti.zcu.cz

Evaluation of cutting tool wear is the technique generally used when monitoring cutting tool life. Different tool wear types increase depending on the cutting conditions and machined material on the cutting edge surface. The evaluated parameters depend on the tool wear type and where the tool wear is created. All these parameters are described by ISO 3685 standards. When a standard optical microscope is used, it is very difficult to determine the volumetric parameters and, in many cases, the actual (real) area of the tool wear. A standard optical microscope works on the basis of $2 \mathrm{D}$ screening. The new microscope works on the basis of 3D scanning, so the user has full information about the surface. This article is focused on the evaluation of the volumetric parameters on the cutting edge, on the size of the built up edge (BUE), and on the formation of the crater. Different coating types on the cutting inserts were used for the testing, and a IFM G4 microscope was used for monitoring and evaluating the tool wear.

Keywords: Cutting tool wear, 3D scanning, Crater tool wear, Built up Edge (BUE)

\section{Acknowledgement}

The present contribution has been prepared under project LO1502 'Development of the Regional Technological Institute' under the auspices of the National Sustainability Programme I of the Ministry of Education of the Czech Republic aimed at supporting research, experimental development and innovation.

\section{References}

[1] KOLAR, P., SULITKA, M., FOJTU゚, P., FALTA, J., ŠINDLER, J. (2015). Cutting force modelling with a combined influence of tool wear and tool geometry. In: Manufacturing Technology, Vol. 3, pp. 524-531. Univerzita J. E. Purkyne, Czech Republic

[2] PETRU, J., SCHIFFNER, J., ZLAMAL, T., SADILEK, M., STANCEKOVA, D. (2015). Investigations of cutting tool wear while machining inconel 718. In: Manufacturing technology, vol. 3, pp. 396-403. Univerzita J. E. Purkyne, Czech Republic

[3] COPPEL, R., ABEllan-NEBOT, J.V., SILlER, H.R., RODRIGUEZ, C.A., GUEDEA, F. (2016). Adaptive control optimization in micro-milling of hardened steels evaluation of optimization approaches. In: International Journal of Advanced Manufacturing Technology, vol. 9-12, pp. 2219-2238. Springer-Verlag London Ltd, UK

[4] DUTTA, S., PAL, S.K., SEN, R. (2016). Tool condition monitoring in turning by applying machine vision. In: Journal of Manufacturing Science and Engineering, Transactions of the ASME, Vol. 5. American Society of Mechanical Engineers (ASME), USA

[5] ČERČE, L., PUŠAVEC, F., KOPAČ, J. (2015). 3D cutting tool wear monitoring in the proces. In: Journal of Mechanical Science and Technology, vol. 9, pp. 3885-3895. Korean Society of Mechanical Engineers, Korea

[6] MADL, J., MARTINOVSKY, M.Cutting tool wear monitoring. In: (2015) Manufacturing Technology, vol. 3, pp. 380-384. Univerzita J. E. Purkyne, Czech Republic 